\title{
Metafora Waktu dan Penalaran Temporal dalam Perspektif Budaya Waktu
}

\section{Time Metaphor and Temporal Reasoning in the Cultural Perspective of Time}

\author{
Dyah Triarini Indirasari ${ }^{1}$, Harry Susianto ${ }^{2}$, Guritnaningsih $^{3}$
}

Fakultas Psikologi, Universitas Indonesia

\begin{abstract}
Time is an abstract concept that can be understood by making an analogy or a metaphor from a more concrete concept such as a spatial construct. Previous studies found that people from different cultures and languages constructed time movement differently. In addition, the use of specific time metaphor tends to activate different type of temporal reasoning. Time metaphor studies related to Indonesian's culture and language are still limited. Although it is known that Indonesians tend to use different temporal reasoning compare to other countries, how their time metaphors may have impact on their temporal reasoning is still unknown. It is then important to further investigate the effect of time metaphor on time reasoning particularly in different cultural contexts and how it may have impact on people behavior. This paper will discuss some findings in the topic of time metaphor and temporal reasoning, including the influence of culture on time conception.
\end{abstract}

Keywords: time metaphor; temporal reasoning; time and culture

Abstrak. Waktu adalah konsep abstrak yang dapat dipahami secara metaforis dengan membuat analogi dari ranah lain seperti ranah spasial. Sejumlah penelitian menemukan bahwa setiap bahasa dan budaya bisa berbeda dalam cara mereka menjelaskan pergerakan waktu secara spasial, dan pengaruh dari penggunaan metafora waktu tertentu akan menyebabkan aktivasi berbagai jenis penalaran temporal yang berbeda. Penelitian tentang bagaimana waktu dimetaforakan dalam konteks budaya dan bahasa Indonesia sendiri masih belum banyak didalami. Studi yang dilakukan dalam konteks bahasa Indonesia menunjukkan bahwa orang Indonesia menggunakan penalaran temporal yang berbeda dibandingkan orang dari budaya yang berbeda. Namun apakah adanya perbedaan penalaran temporal tersebut disebabkan oleh metafora waktu yang berbeda yang terkandung dalam bahasa Indonesia masih belum dibuktikan. Oleh sebab itu studi yang melihat efek dari metafora waktu terhadap penalaran temporal terutama dalam konteks budaya yang berbeda dan pengaruhnya terhadap tingkah laku perlu dilakukan. Tulisan ini akan menjelaskan beberapa temuan dalam bidang metafora waktu dan penalaran temporal, serta berbagai konsepsi waktu antar budaya.

Kata kunci: metafora waktu; penalaran temporal; waktu dan budaya

\section{Pengantar}

Kebiasaan orang Indonesia dalam menepati waktu seringkali dibandingkan

\footnotetext{
${ }^{1}$ Korespondensi mengenai artikel ini dapat melalui: dyahti@ui.ac.id
}

dengan orang dari budaya Barat, khususnya budaya Anglo-Amerika. Adanya kebiasaan terlambat atau 'molor' dalam melaksanakan suatu aktivitas merupakan hal yang kerap ditemui dalam situasi sehari-hari di Indonesia. Tingkah laku ini 
berbeda dengan orang-orang dari budaya Anglo Amerika, yang cenderung lebih menekankan ketepatan waktu dalam menjalankan berbagai aktivitas.

Dalam budaya Anglo-Amerika yang menggunakan bahasa Inggris, misalnya, waktu seringkali disamakan dengan uang atau time is money. Dalam pandangan ini waktu dianggap memiliki nilai komoditas yang bisa digunakan sebagai alat jual beli dan merupakan sumber yang terbatas sehingga pemakaiannya perlu diperhitungkan dengan baik (Lakoff \& Johnson, 1980). Adanya pepatah 'time is money' tersebut menyebabkan, dalam bertingkah laku, waktu menjadi satu faktor penting yang perlu diperhitungkan saat melakukan suatu kegiatan. Hal ini bisa dilihat misalnya dalam perencanaan kerja, kebiasaan tepat waktu, sistem pembayaran berdasarkan jumlah jam kerja, dan sebagainya (Graham, 1981).

Di Indonesia sendiri, ketidaktepatan waktu dalam menjalankan suatu kegiatan menjadi hal yang lumrah dan sering terjadi, baik dalam skala kecil dan besar, seperti terlambat masuk kerja, waktu kegiatan yang dimundurkan dari jadwal yang seharusnya, hingga pekerjaan konstruksi yang tidak selesai sesuai dengan perkiraan. Adanya ciri budaya 'jam karet' di Indonesia (Levine \& Norenzayan, 1999; White, Valk, \& Dialmy, 2011) menunjukkan bahwa ada suatu keunikan dalam pemahaman tentang waktu yang bisa jadi berbeda dengan budaya lain. Penelitian lintas-budaya yang dilakukan oleh Levine dan Norenzayan (1999) yang membandingkan kecepatan kehidupan (pace of life) di beberapa negara termasuk Indonesia juga menunjukkan bahwa indeks kecepatan kehidupan Indonesia yang berada di posisi ke-30 dari 31 negara yang diteliti. Pengukuran kecepatan kehidupan dalam penelitian
Levine dan Norenzayan (1999) dilakukan berdasarkan tiga kriteria, yakni: rata-rata kecepatan orang berjalan di tengah kota, ketepatan jam penunjuk waktu di beberapa tempat umum, dan kecepatan pelayanan di kantor pos. Ketiga indikator yang digunakan dalam penelitian Levine dan Norenzayan (1999) tersebut merupakan indikator tingkah laku yang terkait dengan waktu. Adanya indeks kecepatan kehidupan yang berbeda antar negara tersebut bisa menggambarkan adanya suatu pemahaman tentang waktu yang berbeda antar budaya.

Apa sebenarnya yang mendasari adanya perbedaan tingkah laku dalam menyikapi waktu? Jika waktu merupakan suatu konsep yang bisa dipahami secara universal, mengapa konsep waktu bisa dipahami secara berbeda antar budaya? Untuk mengetahui secara lebih mendalam tentang konsep waktu, tulisan ini akan mengulas perbedaan konsep waktu yang bisa dimiliki antar budaya dan bagaimana perbedaan ini bisa memengaruhi proses kognitif manusia.

\section{Pembahasan}

\section{Konsep Waktu dan Budaya}

Waktu merupakan suatu konsep abstrak yang sebagai objek tidak bisa dilihat secara langsung sehingga pembelajaran tentang konsep waktu diperoleh berdasarkan pengalaman maupun sosialisasi konsep waktu yang diajarkan dalam suatu budaya (Graham, 1981). Menurut Graham (1981) ada tiga model persepsi waktu yang dimiliki oleh budaya-budaya yang ada di dunia, yakni: linear-separable, circulartraditional, dan procedural traditional.

Pada model linear-separable, pergerakan waktu dilihat dalam konteks linearitas di mana waktu dipersepsikan sebagai suatu garis yang membentang dari 
masa lalu hingga masa depan. Adanya ciri linearitas ini menyebabkan waktu terbagi atas masa lalu, masa sekarang, dan masa depan yang terpisah-pisah satu sama lain. Masa lalu mencerminkan segala kejadian yang sudah terjadi dan tidak bisa diulang, dan masa depan adalah suatu hal yang baru dan bisa dipersiapkan di masa sekarang. Selain adanya pembagian waktu, pada budaya waktu linear-separable, orang cenderung mengerjakan satu hal dalam satu waktu. Hal ini yang kemudian menyebabkan waktu lebih mudah dipersepsikan sebagai suatu komoditas yang bisa dibandingkan dengan uang atau barang yang memiliki nilai. Meskipun setiap budaya juga seringkali menggunakan uang sebagai pengganti pengukuran waktu, namun dalam konsep linearseparable waktu yang dinilai sama dengan uang lebih memiliki nilai investasi untuk masa depan. Model linear-separable ini menurut Graham (1981) lebih banyak dijumpai pada budaya Anglo-Amerika.

Dalam model circular-traditional, waktu tidak dilihat sebagai garis yang membentang tetapi dilihat sebagai suatu siklus dimana kejadian yang sama bisa berulang mengikui suatu pola. Pada budaya yang mengadopsi model circulartraditional ini, tingkah laku tidak diatur oleh waktu (jam), melainkan oleh siklus dari alam (pergerakan bulan atau matahari, musim, pertanian, dan sebagainya). Adanya pemahaman waktu yang merupakan suatu siklus ini menyebabkan masa depan dilihat sebagai pengulangan dari masa lalu sehingga tidak ada sesuatu yang diantisipasi pada masa depan. Budaya yang menggunakan model ini memiliki ciri lebih mengutamakan masa sekarang. Pengaruh dari pandangan ini, menurut Graham (1981), adalah tidak adanya pembagian waktu dan penggunaan waktu tidak perlu direncanakan. Hal ini menyebabkan pada satu waktu yang sama beberapa kegiatan bisa dilakukan secara bersamaan.

Pada model ketiga, yakni proceduraltraditional, pelaksanaan suatu aktivitas lebih dilihat sebagai suatu hal yang harus dilakukan sesuai prosedur, bukan ditentukan oleh waktu. Akibatnya, dalam model ini, jumlah waktu yang perlu dilakukan dalam menjalankan aktivitas menjadi hal yang tidak penting. Pelaksanaan kegiatan sesuai dengan prosedur yang ada menjadi lebih diutamakan dalam menjalankan kegiatan. Model procedural-traditional ini, menurut Graham (1981) lebih sering dimiliki oleh budaya yang lebih menekankan pada suatu tradisi atau pelaksanaan ritual sehingga penekanan lebih pada masa kini. Waktu yang menentukan kapan suatu ritual akan dilaksanakan ditetapkan pada saat waktu tersebut dirasakan tepat untuk melakukan ritual tersebut. Adanya pandangan yang sangat tidak terpaku dengan waktu menyebabkan konsep perencanaan kegiatan tidak pernah ada dalam budaya ini. Pada saat suatu aktivitas atau ritual dimulai, maka prosesproses yang dilewati harus lebih diutamakan daripada waktu yang berjalan. Dalam model ini, pembandingan waktu sebagai suatu komoditas yang bisa dinilai sebagai uang juga menjadi hal yang tidak bisa dilakukan.

Adanya ketiga model tersebut mencerminkan bahwa waktu tidak dipersepsikan secara universal. Hasil-hasil penelitian yang membandingkan antara kebiasaan orang dari budaya Barat dan Timur mendukung adanya perbedaan tingkah laku terkait waktu sejalan dengan penjelasan dari Graham (1981). Penelitian dari Ji, Guo, Zhang, dan Messervey (2009) yang membandingkan orientasi temporal antara orang Cina dan Kanada memperlihatkan bahwa dalam partisipan Cina 
melihat masa lalu lebih dekat dengan masa sekarang, sedangkan partisipan Kanada melihat masa depan lebih dekat dengan masa sekarang. Hal ini menunjukkan bahwa budaya Cina cenderung lebih berpegangan pada masa lalu dibanding masa sekarang. Hasil ini juga didukung oleh penelitian dari Guo, Ji, Spina, dan Zhang (2012) yang juga menunjukkan bahwa orang Eropa Kanada cenderung menekankan nilai dari uang untuk kepentingan masa depan, dibanding masa lalu. Hal yang sebaliknya dimiliki oleh orang Cina dan Cina Kanada di mana uang lebih dinilai dalam konteks masa lalu dibanding masa depan. Ji, Guo, Zhang, dan Messervey (2009) lebih lanjut menjelaskan bahwa adanya pemikiran yang berfokus pada masa lalu menyebabkan perkembangan budaya dan inovasi menjadi lebih lambat dibanding dengan budaya Barat. Akibatnya, perkembangan budaya di Cina menjadi lebih relatif stabil dalam beribu-ribu tahun meskipun adanya perubahan budaya global. Pandangan ini sesuai dengan penelitian dari Yau (1988) yang memperlihatkan bahwa konsumen Cina lebih bisa bertahan dengan menggunakan produk yang telah dimiliki dibanding membeli produk baru yang lebih inovatif. Apabila dilihat kembali pada ketiga model waktu dari Graham (1981), hasil-hasil penelitian tersebut menunjukkan bahwa dalam budaya Timur (Cina) berjalannya waktu bisa dilihat sebagai suatu proses yang lebih mencerminkan pada budaya circulartraditional, sedangkan budaya Barat lebih mengarah pada model linear-separable.

\section{Metafora Waktu}

Untuk bisa mengkaji secara lebih mendalam bagaimana suatu budaya memahami konsep waktu, pendekatan lain yang bisa digunakan adalah melalui bahasa yang digunakan. Menurut Lakoff dan Johnson (1980), bagaimana suatu budaya memahami suatu konsep yang sifatnya abstrak seperti waktu bisa dipahami melalui metafora-metafora yang digunakan dalam bahasa dari budaya tersebut. Dalam Kamus Besar Bahasa Indonesia (KBBI) metafora didefinisikan sebagai "pemakaian kata atau kelompok kata bukan dengan arti yang sebenarnya, melainkan sebagai lukisan yang berdasarkan persamaan atau perbandingan" (KBBI, n.d.). Pandangan Representasi Metaforik (Metaphoric Representation) dari Lakoff dan Johnson (1980) menjelaskan bahwa metafora merupakan suatu bentuk analogi antara konsep abstrak dengan konsep lain yang lebih konkrit di mana ciri atau karakteristik dari konsep konkret tersebut digunakan untuk menjelaskan konsep yang lebih abstrak. Secara lebih rinci, pandangan ini menjelaskan bahwa konsep abstrak yang dijelaskan disebut sebagai target domain (ranah utama), sedangkan konsep lain yang digunakan sebagai analogi merupakan source domain (ranah sumber). Dalam konteks di mana waktu dimetaforakan sebagai uang, misalnya, maka konsep tentang uang akan digunakan sebagai ranah sumber dalam menjelaskan tentang konsep waktu (ranah utama). Hal ini menyebabkan pada saat seseorang berpikir tentang waktu, maka ciri dari uang sebagai komoditas yang bisa diperjualbelikan, misalnya, bisa digunakan untuk menghitung jumlah waktu yang sudah berlalu.

Apabila setiap orang bisa memahami tentang waktu, terlepas dari bahasa yang digunakan ataupun budaya di mana dirinya dibesarkan, adakah ciri yang dipahami secara universal dari konsep waktu? Menurut Matlock, Holmes, dan Srinivasan (2011), ada dua ciri universal dari metafora waktu yang berlaku di 
setiap budaya, yakni 'time is space' dan 'time is motion' atau waktu bisa dianalogikan dengan konsep keruangan atau spasial dan waktu memiliki pergerakan.

Contoh dari penggunaan ranah spasial atau keruangan dan pergerakan dalam menjelaskan tentang waktu, bisa dilihat salah satunya pada metafora waktu yang terkandung dalam bahasa Inggris. Dalam konteks bahasa Inggris, ada dua jenis metafora spasial yang bisa digunakan untuk menjelaskan tentang konsep waktu, yakni metafora ego-moving dan metafora time-moving (Boroditsky, 2000; McGlone \& Harding, 1998) (lihat Gambar 1).

\section{Metafora Ego-moving}

Pergerakan waktu secara spasial pada metafora ini dianalogikan mengacu pada "ego" atau pandangan pengamat yang berjalan ke arah masa depan. Dalam metafora ini masa lalu digambarkan bergerak menuju masa depan yang disebabkan oleh adanya pergerakan diri individu. Hal ini seperti terlihat pada pemaknaan kalimat "Kita sudah mendekati Tahun Baru".

\section{Metafora Time-moving}

Pergerakan waktu secara spasial pada metafora ini dianalogikan sebagai suatu alur yang bergerak masa depan ke masa lalu. Pada metafora ini individu digambarkan dalam kondisi diam (stationary) dan waktu yang melatarbelakangi kejadian mengalir dari masa depan ke arah masa lalu. Hal ini dapat terlihat pada pemaknaan kalimat "Tahun Baru sebentar lagi datang".

(a)

\title{
PAST
}

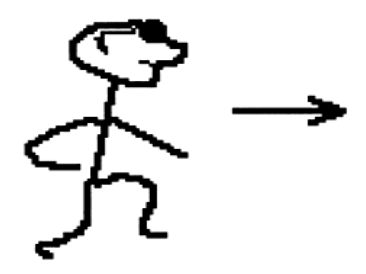

FUTURE

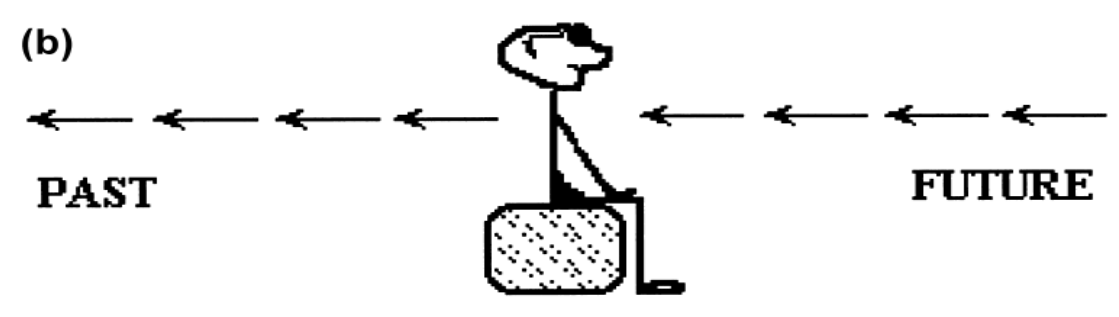

\begin{abstract}
Gambar 1. (a) Gambaran dari pergerakan waktu yang dijelaskan melalui metafora egomoving dimana individu bergerak sejalan dengan waktu, yakni dari masa lalu yang berada di belakang individu menuju masa depan yang berada di depan diri individu; (b) Gambaran dari pergerakan waktu yang dijelaskan melalui metafora time-moving dimana individu berada dalam kondisi diam dan waktu bergerak dari masa depan (yang berada di depan individu) menuju masa lalu (yang berada di belakang individu). Perbedaan kedua metafora bisa terlihat dari posisi masa lalu dan masa depan dari sudut pandang individu (ego-reference) dan arah panah pergerakan waktu. (Boroditsky, 2000).
\end{abstract}


Untuk membuktikan adanya metafora-metafora tersebut, Boroditsky (2000) melakukan serangkaian eksperimen yang membuktikan bagaimana metafora waktu berpengaruh terhadap tingkah laku melalui penganalogian dari ranah spasial. Penelitian dari Boroditsky dan Ramscar (2002) memperlihatkan bahwa apabila partisipan di-priming dengan metafora waktu yang berbeda (ego-moving vs. timemoving), mereka akan menjawab secara berbeda pada pertanyaan ambigu: "Pertemuan hari Rabu mendatang dimajukan dua hari ke depan. Pada hari apakah pertemuan tersebut akan dilaksanakan?". Hasil penelitian menunjukkan bahwa partisipan yang di-priming dengan metafora ego-moving akan cenderung menjawab hari Jumat, sedangkan partisipan yang dipriming dengan metafora time-moving akan cenderung menjawab hari Senin. Pembuktian dari adanya penalaran temporal yang berbeda ini tidak hanya terjadi pada situasi imajiner tetapi juga dalam situasi yang nyata. Studi 1 penelitian dari Boroditsky dan Ramscar (2002) menunjukkan bahwa pada saat partisipan diminta mengimajinasikan atau membayangkan dirinya menarik sebuah kursi menuju dirinya, metafora time-moving akan lebih teraktivasi. Sebaliknya, saat partisipan diminta untuk membayangkan dirinya duduk di atas kursi dan bergerak ke arah depan, maka metafora ego-moving akan teraktivasi. Priming pada studi ini dilakukan dengan meminta partisipan untuk membayangkan bagaimana dirinya "menggerakkan sebuah kursi ke titik X", di mana pergerakan waktu kemudian dianalogikan dengan pergerakan kursi tersebut. Pada metafora time-moving, titik $\mathrm{X}$ adalah titik di mana partisipan berdiri, sehingga kursi digerakkan menuju diri partisipan. Pada manipulasi metafora egomoving, partisipan duduk di atas kursi yang jika digerakkan maka dirinya juga akan ikut bergerak ke arah titik $X$ yang ada di ujung (lihat Gambar 2).

Priming Ego-Moving

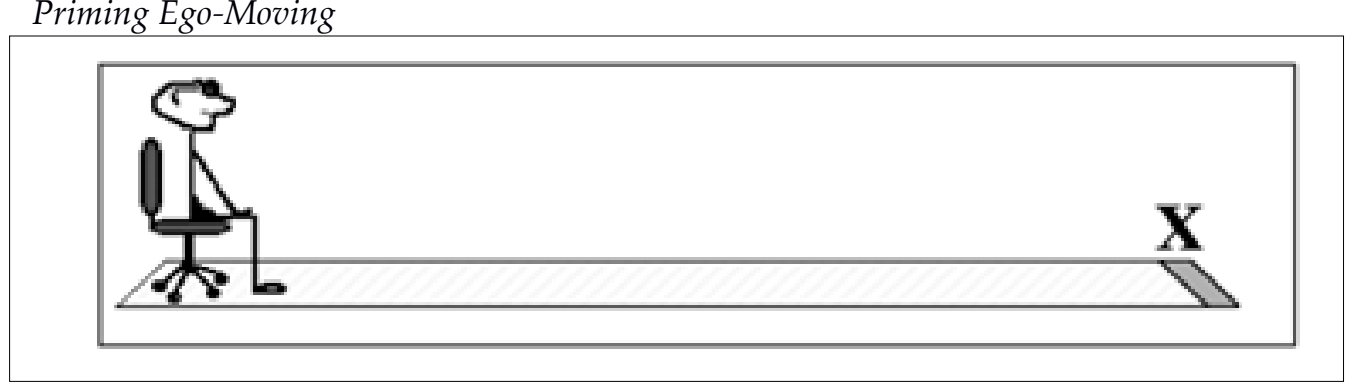

Priming Time-Moving

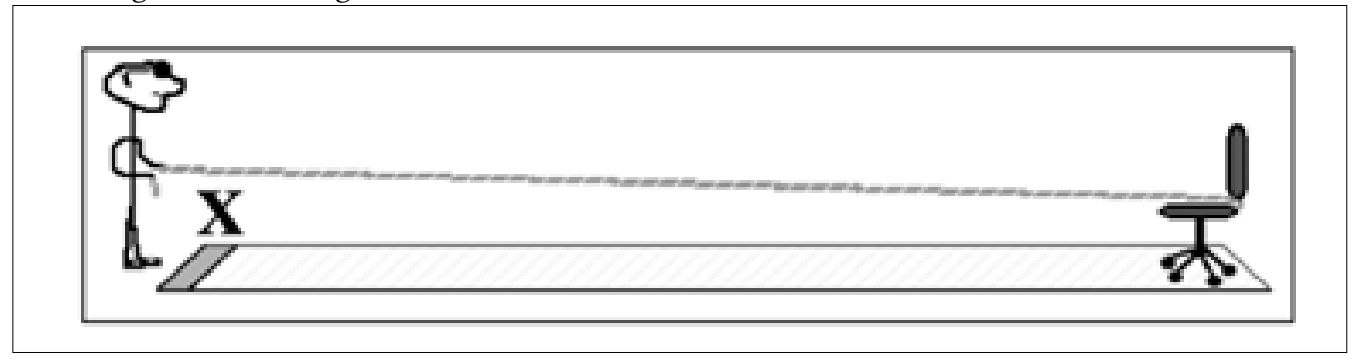

Gambar 2. Pada kondisi priming ego-moving, partisipan diminta membayangkan dirinya duduk di kursi dan bergerak mengarahkan kursi ke titik X. Partisipan diminta membuat garis panah pada gambar yang menunjukkan arah dari pergerakan kursi. Pada kondisi priming time-moving, partisipan diminta membayangkan dirinya menarik kursi dan mengarahkannya ke titik X. Partisipan diminta membuat garis panah pada gambar yang menunjukkan arah pergerakan kursi. (Boroditsky dan Ramscar, 2002). 
Selain menggunakan priming yang bersifat imajiner, pembuktian metafora juga dilakukan pada kondisi nyata saat seseorang sedang mengantri (Studi 2) (Boroditsky \& Ramscar, 2002). Studi 2 dilakukan pada kondisi di mana partisipan sedang dalam posisi mengantre makan siang di sebuah kafe universitas. Panjang antrean sekitar 50 meter dengan waktu tunggu kurang lebih 10 menit. Pada saat partisipan sedang mengantre, eksperimenter menanyakan berapa lama mereka telah mengantre serta mencatat posisi partisipan di antrean. Selanjutnya, mereka diberi pertanyaan ambigu tentang pertemuan hari Rabu yang dimajukan dua hari ke depan. Hasil pengolahan data dari 70 orang partisipan terlihat bahwa orang yang berada di posisi depan sebuah antrean akan cenderung menggunakan metafora ego-moving, dan sebaliknya orang yang ada di posisi akhir sebuah antrean cenderung menggunakan metafora timemoving (Boroditsky \& Ramscar, 2002). Adanya hasil-hasil penelitian dari Boroditsky dan Ramscar (2002) tersebut menunjukkan bahwa metafora tentang waktu bisa teraktivasi saat individu membayangkan dirinya bergerak dalam konteks spasial, baik dalam situasi yang bersifat imajiner maupun dalam kondisi nyata.

Metafora waktu dalam konteks spasial tersebut juga memiliki ciri hubungan yang bersifat satu arah, yang berarti bahwa waktu bisa dijelaskan menggunakan analogi konsep spasial, namun konsep spasial sendiri tidak bisa dijelaskan menggunakan konsep waktu (Boroditsky, 2000). Metafora waktu berdasarkan ranah spasial bisa terlihat misalnya melalui ungkapan-ungkapan seperti: 'waktu rasanya bergerak cepat', 'lamban sekali waktu bergerak', atau 'kita seperti dikejar waktu'.
Apakah kemudian setiap bahasa memiliki metafora waktu ego-moving dan time-moving? Pandangan bahwa metafora waktu digambarkan secara ego-moving dan time-moving, menurut Núñez, Motz, \& Teuscher (2006), merupakan pandangan yang melihat pergerakan waktu dari sudut pandang diri individu (ego-reference point). Menurut Núñez, Motz, dan Teuscher (2006) pergerakan waktu tidak hanya bisa dilihat berdasarkan ego-reference point, tetapi juga bisa dilihat dari sudut pandang bagaimana waktu itu sendiri bergerak atau disebut sebagai time-reference point. Hasil penelitian yang dilakukan oleh Núñez, Motz, dan Teuscher (2006) menunjukkan bahwa ketika waktu dirasakan bergerak, pergerakan waktu bisa dilihat berdasarkan urutan kejadian di mana kejadian yang baru selalu berada di 'depan' kejadian yang sebelumnya. Penentuan arah dari 'depan' selanjutnya bisa dianalogikan berdasarkan ranah dari konsep yang lain. Sudut pandang ini tidak menekankan pada siapa yang bergerak (diri atau waktu) seperti yang dijelaskan berdasarkan sudut pandang ego-reference point, tetapi lebih menekankan pada urutan dari objek. Dengan demikian, apabila menggunakan penjelasan berdasarkan time-reference point, maka jawaban dari pertanyaan "Pertemuan hari Rabu mendatang dimajukan dua hari ke depan. Pada hari apakah pertemuan tersebut akan dilaksanakan?", akan lebih mengarah pada orientasi depan dan belakang dari urutan objek tersebut. Jika urutan hari dalam satu minggu (Senin hingga Minggu) dipersepsikan memiliki urutan di mana hari Senin lebih awal (depan) daripada hari Selasa, Rabu, dan seterusnya, maka jawaban dari pertanyaan tersebut menjadi hari Senin dan tidak ada jawaban hari Jumat. 
Casasanto (2010) lebih lanjut menjelaskan bahwa hasil-hasil studi yang telah dilakukan terkait metafora waktu memberikan bukti-bukti bahwa (1) orang tidak hanya berbicara waktu dalam konteks spasial, tetapi mereka juga berpikir dengan cara tersebut; (2) orang yang menggunakan metafora spasial temporal berbeda akan berpikir tentang waktu secara berbeda, dan (3) mempelajari metafora spasial baru akan mengubah representasi mental seseorang tentang waktu.

\section{Waktu dan Penalaran Temporal}

Penelitian-penelitian yang telah dilakukan terkait dengan metafora waktu selanjutnya memperlihatkan bahwa metafora waktu bisa berpengaruh terhadap proses kognitif manusia, khususnya dalam konteks penalaran temporal (Boroditsky, 2000; Boroditsky \& Ramscar, 2002; Fuhrman et al., 2011). Penalaran temporal merupakan pemikiran bahwa waktu dikonsepsikan sebagai suatu objek yang memiliki ciri unidimensional dan mempunyai urutan (Gentner, 2001). Adanya ciri unidimensional ini mengakibatkan waktu biasa dijelaskan berdasarkan awal/akhir atau atas/bawah. Hal ini berbeda dengan konsep yang memiliki ciri dua atau tiga dimensi, di mana istilah sempit/luas atau dangkal/dalam bisa digunakan. Ciri kedua, yakni waktu memiliki urutan, menunjukkan bahwa kejadian-kejadian bisa diurutkan dalam suatu kontinum yang menggambarkan kejadian yang lebih awal/akhir atau sesudah/sebelum (Gentner, 2001).

Dalam setiap budaya, konsepsi waktu dalam konteks penalaran temporal bisa berbeda. Hasil-hasil studi yang telah dilakukan terkait metafora waktu menunjukkan bagaimana arah pergerakan ataupun urutan waktu yang dijelaskan secara spasial bisa menunjukkan adanya pemahaman waktu yang berbeda antar budaya atau bahasa. Penelitian dari Fuhrman dan Boroditsky (2010), misalnya, menunjukkan bahwa pengguna bahasa Ibrani yang terbiasa membaca dan menulis dari arah kanan ke kiri akan cenderung melihat arah pergerakan waktu dari awal ke akhir juga dari kanan ke kiri. Hal ini berbeda dengan pengguna bahasa Inggris yang cenderung mengatur urutan kejadian (awal ke akhir) dari kiri ke kanan. Selanjutnya, penelitian dari Boroditsky, Fuhrman, dan McCormick (2011) juga memperlihatkan bahwa pemahaman arah pergerakan waktu terlihat berbeda dalam konteks bahasa Mandarin dan bahasa Inggris. Pembicara bahasa Mandarin, misalnya, lebih memiliki kecenderungan untuk mengatur urutan waktu atau kejadian secara vertikal, di mana kejadian yang awal diposisikan lebih atas daripada yang terakhir. Di sisi lain, pembicara bahasa Inggris cenderung mengurutkan waktu dan kejadian secara horizontal. Penelitian lain yang dilakukan di kelompok budaya yang menggunakan bahasa Aymara di bagian barat Bolovia, tenggara Peru dan utara Chili menemukan bahwa kata yang merepresentasikan konsep 'depan' diekspresikan sebagai sesuatu hal yang berada di 'masa lalu', sedangkan kata 'belakang' diekspresikan sebagai 'masa depan' (Núñez \& Sweetser, 2006).

Hasil penelitian juga memperlihatkan bahwa penalaran temporal yang berbeda tersebut selanjutnya bisa menyebabkan adanya proses berpikir yang berbeda pada saat mengonseptualisasikan tentang waktu. Hal ini bisa terlihat, misalnya, ketika arah pergerakan waktu secara spasial dimanipulasi secara berbeda atau bahasa yang digunakan berbeda. Penelitian dari Casasanto et al. (2004) yang membandingkan konsep waktu pada 
pengguna bahasa Inggris, bahasa Indonesia, bahasa Yunani, dan bahasa Spanyol menunjukkan bahwa waktu bisa dikonseptualisasikan dan dipersepsikan secara berbeda pada bahasa yang berbeda. Hasil penelitian ini memperlihatkan bahwa penutur bahasa Inggris dan bahasa Indonesia cenderung menggunakan ranah durasi sebagai bentuk analogi dari waktu ('waktunya panjang' atau 'a long time'), sedangkan penutur bahasa Yunani dan Spanyol lebih cenderung menggunakan ranah kuantitas ('waktunya banyak'). Konsekuensi dari adanya penggunaan ranah yang berbeda ini menyebabkan ada perbedaan penalaran temporal antar penutur saat dihadapkan pada stimulus yang bersifat non-linguistik. Pada penelitian tersebut, pengguna bahasa Inggris dan Indonesia cenderung lebih baik dalam melakukan estimasi durasi waktu apabila stimulus yang dihadirkan berupa garis yang semakin memanjang, namun pada pengguna bahasa Yunani dan Spanyol estimasi durasi waktu stimulus lebih mendekati akurasi bila stimulus yang diberikan berupa wadah yang diisi (Casasanto et al., 2004).

Pengaruh dari adanya perbedaan persepsi dalam memandang pergerakan waktu secara spasial ini juga bisa terlihat pada saat seseorang bernalar tentang urutan waktu. Penelitian dari Boroditsky (2001) menunjukkan bahwa penutur dalam bahasa Inggris lebih cepat menilai kalimat yang menjelaskan urutan temporal (misal: Maret lebih dahulu daripada April) ketika di-priming dengan kejadian spasial horizontal, tetapi penutur Mandarin lebih cepat menilai kalimat yang sama ketika di-priming dengan stimulus spasial vertikal. Hal ini juga terbukti meskipun kalimat dipresentasikan dalam bahasa Inggris. Studi lanjutan dari Boroditsky (2001) menemukan bahwa pelatihan metafora urutan waktu secara vertikal pada penutur bahasa Inggris (misal: Maret di atas April) bisa menyebabkan adanya efek priming yang pada akhirnya menghasilkan penalaran temporal yang sama dengan penutur bahasa Mandarin.

\section{Konsep Waktu di Indonesia}

Bagaimana halnya dengan konsep waktu di Indonesia? Sejauh studi literatur yang peneliti lakukan, konsep waktu dalam konteks Indonesia masih belum banyak diteliti. Salah satu penelitian yang telah dilakukan adalah studi antropologi yang dilakukan oleh Geertz (1973) yang menganalisis konsep waktu dalam konteks budaya Bali. Menurut Geertz (1973), konsep waktu pada budaya Bali lebih dipahami sebagai suatu penanda, bukan untuk memperlihatkan berapa lama waktu berjalan atau jumlah waktu yang tersisa untuk menyelesaikan suatu pekerjaan.

... it is adapted to and used for distinguishing and classifying discrete, self-subsistent particles of time - "days". The cycles and supercycles are endless, unanchored, uncountable, and as their internal order has no significance, without climax. They do not accumulate, they do not build, and they are not consumed. They don't tell you what time it is; they tell you what kind of time it is. (Geertz, 1973, h. 393).

Adanya pemahaman waktu dalam konteks tersebut menyebabkan sistem penanggalan yang digunakan dalam budaya Bali lebih menunjukkan, misalnya, kapan suatu ritual perlu dilakukan berdasarkan perhitungan atau siklus yang telah ditetapkan. Penggunaan siklus yang berulang dalam sistem penanggalan ini juga terlihat dalam budaya Jawa. Becker (1981) menjelaskan bahwa budaya Bali 
dan Jawa melihat waktu sebagai suatu hal yang statis dan berulang, bukan sebagai suatu hal yang bersifat progresif. Lebih lanjut, Becker (1981) menjelaskan bahwa, dalam budaya Jawa dan Bali, waktu tidak terlalu digambarkan sebagai suatu objek yang memiliki arah pergerakan maju. Dengan demikian, apabila mengacu pada ketiga model persepsi waktu dari Graham (1981), maka adanya pemahaman tentang waktu yang lebih melihat waktu sebagai suatu siklus dalam budaya Bali dan Jawa bisa lebih dikategorikan ke dalam budaya circular-traditional.

Selain itu, Becker (1981) juga menjelaskan bahwa dalam paparan verbal, bahasa Indonesia cenderung tidak mementingkan waktu dalam penggunaan kalimat (tenseless language). Hal ini berbeda dengan bahasa Inggris yang membedakan bentuk kata kerja tergantung dari waktu kejadian (past, present, atau future). Adanya ciri tenseless language pada bahasa Indonesia ini menyebabkan penutur harus mengucapkan kata keterangan waktu hanya bila dirasa dibutuhkan. Penyebutan kata keterangan waktu merupakan suatu penambahan dan seringkali dihilangkan atau tidak disebutkan (Becker, 1981).

Efek dari penggunaan struktur kalimat yang tidak mementingkan waktu (tenseless language) terhadap proses mental diteliti oleh Boroditsky, Ham, dan Ramscar (2002). Dalam penelitiannya, Boroditsky, Ham, dan Ramscar (2002) melihat pengaruh dari penggunaan tenseless language terhadap penalaran temporal. Studi yang dilakukan oleh Boroditsky, Ham, dan Ramscar (2002) ini merupakan studi eksperimental yang membandingkan penalaran temporal pada penutur bahasa Inggris dan bahasa Indonesia. Dalam studi ini, partisipan diberikan stimulus berupa gambar orang yang melakukan suatu kegiatan (menendang bola, makan pisang, memotong tali, dan sebagainya). Ada tiga jenis gambar yang diberikan dari setiap kegiatan, yakni gambar di mana pelaku kegiatan akan melakukan kegiatan tersebut (perspektif masa depan), sedang melakukan kegiatan (perspektif masa kini), dan setelah melakukan kegiatan (perspektif masa lalu). Pada setiap percobaan (trial), partisipan akan melihat dua gambar yang terdiri dari dua jenis manipulasi, yakni: (a) dilakukan oleh orang yang sama namun menggambarkan perspektif waktu kejadian yang berbeda (masa depan, masa kini, dan masa lalu); dan (b) dilakukan oleh orang yang berbeda namun menggambarkan perspektif waktu kejadian yang sama. Hasil dari eksperimen ini menunjukkan bahwa pada penutur bahasa Inggris, atensi terhadap kemiripan stimulus lebih didasarkan pada kesamaan waktu kegiatan dilakukan (manipulasi b). Sebaliknya, pada orang Indonesia kemiripan lebih didasarkan pada kesamaan pelaku dibanding kesamaan waktu kegiatan dilakukan (manipulasi a). Penelitian dari Boroditsky, Ham, dan Ramscar (2002) ini memperlihatkan bahwa linguistik yang berbeda bisa menyebabkan adanya perbedaan proses kognitif (atensi dan ingatan) yang terjadi pada saat seseorang memproses stimulus visual. Dengan perkataan lain, kebiasaan untuk tidak memikirkan waktu (misal: kapan suatu kejadian terjadi) yang tercermin dalam konteks bahasa Indonesia bisa menyebabkan proses penaralan temporal yang berbeda. Adanya kebiasaan tersebut bisa menyebabkan penutur bahasa Indonesia lebih memberikan atensi pada individu yang melakukan kejadian dibandingkan pada kapan kejadian tersebut terjadi.

Berdasarkan uraian di atas, maka dapat terlihat bahwa meskipun waktu 
dipersepsikan memiliki ciri keruangan dan pergerakan yang berlaku universal, namun waktu bisa dipahami dan dikonseptualisasikan secara berbeda antar budaya dan bahasa. Selanjutnya, adanya perbedaan ini bisa mengakibatkan adanya pola penalaran temporal yang berbeda pada saat seseorang dari suatu budaya tertentu berpikir tentang waktu.

Mengacu pada penjelasan di awal bahwa ada tingkah laku yang berbeda antar budaya Indonesia dengan budaya Anglo-Amerika terkait dengan waktu, bukan tidak mungkin adanya perbedaan tingkah laku tersebut disebabkan oleh adanya proses penalaran temporal yang berbeda yang didasari oleh metaforametafora waktu yang dimiliki oleh budaya tersebut. Pemikiran ini sesuai dengan pandangan Determinisme Linguistik yang menjelaskan bahwa cara berpikir seseorang ditentukan oleh bahasa yang digunakan. Pandangan ini merupakan pandangan yang awalnya dikemukakan oleh Benjamin L. Whorf (1956). Whorf (1956) menjelaskan bahwa konsep dan kategori yang ada pada suatu bahasa dapat memengaruhi proses berpikir individu, seperti persepsi dan analisa, yang pada akhirnya berpengaruh terhadap bagaimana individu bertingkah laku. Adanya perbedaan bahasa akan menyebabkan proses persepsi dan tingkah laku yang berbeda pada situasi yang serupa.

Hasil-hasil penelitian yang telah dijabarkan di atas menunjukkan bahwa pemahaman individu tentang konsep waktu juga bisa memengaruhi proses kognitif khususnya dalam hal penalaran temporal. Efek dari adanya penalaran temporal yang berbeda ini selanjutnya dapat memengaruhi tingkah laku terkait dengan waktu. Salah satu penelitian yang dilakukan oleh Boltz dan Yum (2010) memperlihatkan bahwa priming metafora waktu yang berbeda bisa mengakibatkan estimasi durasi waktu yang berbeda saat partisipan diminta untuk mengestimasi durasi waktu suatu kegiatan. Hal ini menunjukkan bahwa metafora waktu yang digunakan pada suatu bahasa bisa berpengaruh terhadap bagaimana waktu dipersepsikan oleh individu yang selanjutnya memengaruhi estimasi durasi waktu individu.

Dalam konteks budaya atau bahasa Indonesia, bagaimana pergerakan waktu dianalogikan dalam ranah spasial masih belum terlihat dengan jelas. Apakah metafora waktu yang terkandung dalam konteks bahasa Indonesia lebih mengarah pada time-reference point dibanding egoreference point? Diperlukan penelitian yang mendalam dan empiris untuk bisa mengkaji sudut pandang pergerakan waktu dalam konteks bahasa Indonesia. Selain itu, jika mengacu pada pandangan metafora waktu sendiri, maka metaforametafora non-spasial tentang waktu juga perlu digali kembali secara lebih mendalam dalam konteks bahasa Indonesia sehingga pemahaman tentang bagaimana orang Indonesia memahami konsep waktu bisa menjadi lebih dalam dan menyeluruh.

Berdasarkan hasil sensus yang dilakukan oleh Biro Pusat Statistik tahun 2010, negara Indonesia memiliki 1211 bahasa (1158 bahasa daerah) dari 300 kelompok etnis. Pandangan dari Graham (1981) menunjukkan bahwa setiap budaya memiliki ciri yang berbeda dalam memahami konsep waktu. Kajian dari Becker (1981) dan Geertz (1973) juga menunjukkan bahwa produk-produk budaya tentang waktu yang ada di Indonesia, khususnya Bali dan Jawa, memperlihatkan bahwa waktu dilihat sebagai suatu siklus yang selalu berputar dan tidak memiliki klimaks. Apabila mengacu pada pandangan dari Graham (1981), maka ciri 
pemahaman waktu yang ada di Indonesia lebih mengarah pada pandangan circulartraditional. Namun demikian, apakah hal ini juga dipahami secara sama dari kelompok etnis yang ada di Indonesia dan apa pengaruh dari pemahaman waktu secara circular-traditional dalam konteks penalaran temporal dan tingkah laku terkait dengan waktu? Hal-hal tersebut masih perlu digali secara mendalam dan membutuhkan kajian dan penelitian dari berbagai sudut pandang.

\section{Penutup}

Berdasarkan penjelasan di atas terlihat bahwa metafora waktu yang terkandung dalam suatu budaya atau bahasa berperan penting pada saat kita hendak memahami bagaimana individu berpikir atau bernalar tentang waktu. Penelitian-penelitian terkait dengan waktu dan penalaran temporal sudah banyak dilakukan di dunia barat. Namun, hasil-hasil penelitian menunjukkan bahwa suatu budaya dengan bahasa yang berbeda bisa memiliki proses berpikir tentang waktu yang berbeda. Dengan demikian, perlu dilakukan berbagai telaah dan penelitian untuk bisa mendalami tentang konsep waktu dan pengaruhnya terhadap tingkah laku. Di Indonesia sendiri penelitian terkait dengan metafora waktu dalam konteks bahasa Indonesia maupun bahasa daerah perlu dilakukan secara lebih mendalam. Dari sudut pandang psikologi, banyak kondisi psikologis maupun tingkah laku sehari-hari yang bisa dipengaruhi oleh bagaimana seseorang memandang waktu, seperti perencanaan tugas, manajemen waktu, manajemen stres, leisure dan lain sebagainya. Adanya tulisan ini diharapkan bisa membantu pembaca untuk memahami tentang arti penting dari konsep waktu dan bisa menjadi pemicu penelitian-penelitian baru terkait dengan waktu.

\section{Daftar Pustaka}

Becker, J. (1981). Hindu-Buddhist time in Javanese gamelan music. In The Study of Time IV (pp. 161-172). doi: $\underline{10.1007 / 978-1-4612-5947-3 \quad 13}$

Boltz, M. G., \& Yum, Y. N. (2010). Temporal concepts and predicted duration judgments. Journal of Experimental Social Psychology, 46(6), 895-904. doi: 10.1016/j.jesp.2010.07.002

Boroditsky, L. (2000). Metaphoric structuring: understanding time through spatial metaphors. Cognition, 75(1), 1-28. doi: 10.1016/S00100277(99)00073-6

Boroditsky, L. (2001). Does language shape thought?: Mandarin and English speakers' conceptions of time. Cognitive Psychology, 43(1), 1-22. doi: 10.1006/COGP.2001.0748

Boroditsky, L., Fuhrman, O., \& McCormick, K. (2011). Do English and Mandarin speakers think about time differently? Cognition, 118(1), 123-129. doi: $\quad$ 10.1016/I.COGNITION.2010. 09.010

Boroditsky, L., Ham, W., \& Ramscar, M. (2002). What is universal in event perception? Comparing English and Indonesian speakers. Annual Meeting of the Cognitive Science Society. Retrieved from https://cloudfront. escholarship.org/dist/prd/content/qt5j d5w5c8/qt5jd5w5c8.pdf

Boroditsky, L., \& Ramscar, M. (2002). The Roles of Body and Mind in Abstract Thought. Psychological Science, 13(2), 185-189. https://doi.org/10.1111/1467$\underline{9280.00434}$

Casasanto, D. (2010). Space for thinking. In 
V. Evans \& P. Chilton (Eds.), Language, Cognition, and Space (pp. 453-478).

Casasanto, D., Boroditsky, L., Phillips, W., Greene, J., Goswami, S., BocanegraThiel, S., ... Gil, D. (2004). How deep are effects of language on thought? Time estimation in speakers of English, Indonesian. Proceedings of the Annual Meeting of the Cognitive Science Society, (26), 26. Retrieved from https://escholarship.org/uc/item/9m92 g1s5

Fuhrman, O., \& Boroditsky, L. (2010). Cross-cultural differences in mental representations of time: Evidence from an implicit nonlinguistic task. Cognitive Science, 34(8), 1430-1451. doi: 10.1111/j.1551-6709.2010.01105.x

Fuhrman, O., McCormick, K., Chen, E., Jiang, H., Shu, D., Mao, S., \& Boroditsky, L. (2011). How linguistic and cultural forces shape conceptions of time: English and Mandarin time in 3D. Cognitive Science, 35(7), 1305-1328. doi: 10.1111/j.1551-6709.2011.01193.x

Geertz, C. (1973). The interpretation of cultures. New York, NY: Basic Books.

Gentner, D. (2001). Spatial metaphors in temporal reasoning. In M. Gattis (Ed.), Spatial schemas and abstract thought (pp. 203-222). Cambridge, MA, US: The MIT Press.

Graham, R. J. (1981). The role of perception of time in consumer research. Journal of Consumer Research, 7(4), 335-342. doi: $\underline{10.1086 / 208823}$

Guo, T., Ji, L. J., Spina, R., \& Zhang, Z. (2012). Culture, temporal focus, and values of the past and the future. Personality and Social Psychology Bulletin, 38(8), 1030-1040. doi: 10.1177/0146167212443895

Ji, L. J., Guo, T., Zhang, Z., \& Messervey, D. (2009). Looking into the past:
Cultural differences in perception and representation of past information. Journal of Personality and Social Psychology, 96(4), 761-769. doi: $\underline{10.1037 / a 0014498}$

Metafora. (n.d.). In Kamus Besar Bahasa Indonesia (KBBI) Daring. Retrieved from: https://kbbi.kemdikbud.go.id/ entri/metafora

Lakoff, G., \& Johnson, M. (1980). Metaophors we live by. Chicago: University of Chicago Press.

Levine, R. V., \& Norenzayan, a. (1999). The pace of life in 31 countries. Journal of Cross-Cultural Psychology, 30(2), 178205. doi: $10.1177 / 0022022199030002003$

Matlock, T., Holmes, K., \& Srinivasan, M. (2011). Even abstract motion influences the understanding of time. Metaphor and Symbol, 26(4), 260-271. doi: $\underline{10.1080 / 10926488.2011 .609065}$

McGlone, M. S., \& Harding, J. L. (1998). Back (or forward?) to the future: The role of perspective in temporal language comprehension. Journal of Experimental Psychology: Learning Memory and Cognition, 24(5), 12111223. doi: $10.1037 / 0278-7393.24 .5 .1211$

Núñez, R. E., Motz, B. A., \& Teuscher, U. (2006). Time after time: The psychological reality of the ego- and timereference-point distinction in metaphorical construals of time. Metaphor and Symbol, 21(3), 133-146. doi: $10.1207 / \mathrm{s} 15327868 \mathrm{~ms} 21031$

Núñez, R., \& Sweetser, E. (2006). With the future behind them: Convergent evidence from Aymara language and gesture in the crosslinguistic comparison of spatial construals of time. Cognitive Science, 30, 401-450. doi: $10.1207 / \mathrm{s} 15516709 \operatorname{cog} 000062$

White, L. T., Valk, R., \& Dialmy, a. (2011). What is the meaning of "on time"? The 


\section{INDIRASARI, et all}

sociocultural nature of punctuality. Journal of Cross-Cultural Psychology, 42(3), 482-493. doi: 10.1177/0022 $\underline{022110362746}$

Whorf, B. L. (1956). Language, thought, and reality: selected writings of... . In J. B.
Carroll (Ed.) Oxford, England: Technology Press of MIT.

Yau, O. H. M. (1988). Chinese cultural values: Their dimensions and marketing implications. European Journal of Marketing, 22(5), 44-57. doi: $\underline{10.1108 / E U M 0000000005285}$ 